\title{
PRODUCTION PERFORMANCE AND CARCASS QUALITY OF COLOURED BROILERS DIFFERENTIATED GENETIC POTENCIAL FOR GROWTH
}

\author{
Z. Škrbić ${ }^{1}$, Z. Pavlovski ${ }^{1}$, M. Lukić ${ }^{1}$, V. Petričević ${ }^{1}$, D. Milić ${ }^{2}$ \\ ${ }^{1}$ Institute for Animal Husbandry, Autoput 16, 11080, Belgrade, Republic of Serbia \\ ${ }^{2}$ Perutnina Ptuj - Topiko a.d., Petefi Brigade 2, 24300 Bačka Topola, Republic of Serbia \\ Corresponding author: zdskrbic@gmail.com \\ Original scientific paper
}

\begin{abstract}
The study was conducted with the purpose of the comparative analysis of production performance and carcass quality of two coloured broiler genotypes of differentiated genetic potential for growth (Redbro and Redbro Naked Neck) in conditions of intensive feeding, as well as determining the effect of housing system (free range and poultry house) on fattening performance of Redbro broilers. Production performance is presented in the two control periods (days 42 and 84). Carcass quality was analysed at 84 days old broilers based on carcass conformation, yield, share of valuable parts and abdominal fat content. Redbro and Redbro Naked Neck broilers had different growth intensity according to the phases of the experiment, but at the age of 84 days, their body weight did not differ significantly (3382.44g to $3236.0 \mathrm{~g}$ ). Lower efficiency of food utilization $(3.08 \mathrm{~kg}$ to $2.79 \mathrm{~kg}$ ) and improved vitality (100\% vs. $97.33 \%)$ was found in Redbro Naked Neck broilers. In terms of carcass quality, there were no significant differences except in the share of wings. The positive impact of growing Redbro broilers in the poultry house was determined on the body weight $(p<0.05)$, feed efficiency and broiler mortality, which resulted in higher production index (169.83 vs. 140.37) compared to free range reared Redbro chickens. The differences in carcass quality were determined on the basis of better conformation, a small share of the wings but also lower yields of classically dressed carcasses of broilers Redbro reared in the poultry house.
\end{abstract}

Key words: coloured broilers, production performance, carcass quality

\section{Introduction}

The largest part of the total market oriented production of chicken meat still is in intensive broiler production conditions and in this respect the continuous 
increase of the genetic potential for growth of fast-growing broiler genotypes is important. In addition to other necessary technological prerequisites, the maximum production efficiency is provided, which guarantees the lowest price of the product. On the other hand, demands for high quality, safe and healthy food that is produced in accordance with the principles of animal welfare, have caused numerous studies with the aim of comparative analysis of commercial and slow growing genotypes in terms of unconventional production Ristić and Damme, 2002; Grashorn and Serini 2006; Owens et al., 2006) and the development of technological processes to produce chicken meat of special quality (Škrbić et al., 2010). Previous studies of chicken meat production in the revitalized traditional production system in our country, based on the available, few indigenous chicken breeds, pure breeds and some imported slow growing genotypes, resulted in significantly lower final body weight and meat yield (Pavlovski et al., 2009b; Pavlovski et al., 2012; Blagojević et al., 2009) in relation to the conditions of intensive production, which significantly raises the price of the product. Taking into account the results of a survey on consumer willingness to allocate more money for products from nonintensive production systems (Rodić et al., 2003), there is a need to balance between productivity and product quality, and in this regard selection of the appropriate genotype and adjustment of technological process are very important. To this end, a study was performed of the effect of extended fattening of fast growing broiler genotypes in extensive production conditions (BogosavljevićBošković et al., 2007) and an analysis of the production performance of our autochthonous breeds in meat production (Pavlovski et al., 2009a). Owing to the significant development of the part of the world poultry meat market originating from non-intensive housing systems, some breeding companies have created several different genotypes of broilers of slow and moderate growth, i.e. of differentiated genetic potential for growth, with feathers in colour and adapted to different conditions and production targets.

The objective of the study was a comparative analysis of production performance and carcass quality of two coloured broiler genotypes with differentiated genetic potential for growth in conditions of intensive feeding, and to determine the impact of housing system on fattening performance of medium-fast growth broilers.

\section{Materials and methods}

The experiment was conducted using the Hubbard coloured broilers, genotypes Redbro and Redbro Naked Neck, genetically predisposed to different intensity and speed of growth. In the first phase of the experiment, up to 42 days of age, broilers were reared in floor system in a box with a stocking density of 12 birds $/ \mathrm{m}^{2}, 50$ heads/box and 3 repetitions, in total 150 birds per genotype. In addition, another 150 Redbro broilers were included with the same housing 
conditions in the facility until the slaughter age ( 84 days). Intensive feeding conditions were used in order to maximize growth and achieve better fattening performance (starter $22.2 \% \mathrm{CP}$ and $3100 \mathrm{Kcal} / \mathrm{kg}$; Grower $19.4 \% \mathrm{CP}$ and 3110 $\mathrm{Kcal} / \mathrm{kg}$ and finisher, containing $17.3 \% \mathrm{CP}$ and $3170 \mathrm{Kcal} / \mathrm{kg}$ ). The light program was following: the period $0-7$ days $23 \mathrm{~L}: 1 \mathrm{D}$ and thereafter $16 \mathrm{~L}: 4 \mathrm{D}: 2 \mathrm{~L}: 2 \mathrm{D}$. In the second phase of the experiment, in the period from 43-84 days of age, broilers were reared in the free range system. Also at this stage of the experiment, the diet was based on the complete mixture $(17 \% \mathrm{CP}, 3170 \mathrm{Kcal} / \mathrm{kg})$ and broilers in the poultry house with range had free access to pasture $10 \mathrm{~m}^{2} / \mathrm{bird}$. Control of body weight was performed by measuring individual broilers at the age of 42 and 84 days, while group food consumption was recorded for genotypes and therefore only the average feed conversion is presented. Mortality were recorded daily by the box, i.e. genotype. The production index was calculated according the following formula:

$\mathrm{PI}=\frac{\text { Body weight, } \mathrm{kg} \times \mathrm{(100} \text {-\% mortality }) \times 100}{\text { Fattening duration, days } \mathrm{x} \text { feed conversion, } \mathrm{kg}}$

The investigation of the carcass quality, based on measures of carcass conformation (Pavlovski et al., 2006), yields of classically dressed carcass, carcass ready to roast, carcass ready to grill, share of valuable carcass parts (breasts, thighs, drumsticks, wings) and abdominal fat content in the carcass, which are expressed relative to body weight of broilers at slaughter, was performed on a random sample formed of 12 broilers ( 6 per gender) per genotype, i.e. the housing system for Redbro broilers.

Statistical analysis was performed by analysis of variance in the software program Statistica (Stat.Soft, Inc. version 6). Data expressed in percentages were previously transformed to arcsin. The evaluation of significance of mean values was performed using the Tukey test.

\section{Results and Discussion}

Control of production performance of Redbro and Redbro Naked Neck broilers at the age of 42 days (Table 1) showed significantly higher body weight and lower food efficiency of Redbro chickens. Intensive growth of Redbro Naked Neck broilers in the second phase of the experiment resulted in final body weight without significant statistical difference compared to Redbro broilers in free range system of rearing, at the age of 84 days (Table 2). Feed conversion ratio was worse in Redbro Naked Neck, as opposed to the vitality of these chickens. 
Table 1. Production performance of Redbro and Redbro Naked Neck broilers at the age of 42 days

\begin{tabular}{|l|c|c|}
\hline \multirow{2}{*}{ Genotype } & \multicolumn{2}{|c|}{ 42 days } \\
\cline { 2 - 3 } Production performance & Redbro & Redbro Naked Neck \\
\hline Body weight, $\mathrm{g}$ & $1581.61^{\mathrm{a}} \pm 261.54$ & $1156.00^{\mathrm{b}} \pm 168.96$ \\
\hline Feed conversion, $\mathrm{kg}$ & $2.14^{\mathrm{a}} \pm 0.07$ & $1.78^{\mathrm{b}} \pm 0.05$ \\
\hline Mortality, \% & 0.34 & 0 \\
\hline
\end{tabular}

*a-b means in the same row with different letters are significantly different $(\mathrm{p}<0.05)$

Table 2. Production performance of broilers at the age of 84 days

\begin{tabular}{|l|c|c|c|}
\hline \multirow{2}{*}{$\begin{array}{c}\text { Genotype/housing system } \\
\text { Production performance }\end{array}$} & \multicolumn{3}{|c|}{84 days } \\
\cline { 2 - 4 } & $\begin{array}{c}\text { Redbro/ } \\
\text { free range }\end{array}$ & $\begin{array}{c}\text { Redbro Naked Neck/ } \\
\text { free range }\end{array}$ & $\begin{array}{c}\text { Redbro/ } \\
\text { poultry house }\end{array}$ \\
\hline Body weight, g & $3382.44^{\mathrm{b}} \pm 494.51$ & $3236.00^{\mathrm{b}} \pm 436.56$ & $3626.87^{\mathrm{a}} \pm 645.54$ \\
\hline Feed conversion, $\mathrm{kg}$ & 2.79 & 3.08 & 2.51 \\
\hline Mortality, \% & 2.67 & 0 & 1.36 \\
\hline Production index & 140.37 & 125.23 & 169.83 \\
\hline
\end{tabular}

*a-b means in the same row with different letters are significantly different $(\mathrm{p}<0.05)$

Growing broilers at constant high temperatures can have an adverse effect on the growth rate and the differences between the genotypes associated with the genetic potential for growth (Yalcin et al., 1997). In conditions of summer temperature and free range rearing, Redbro Naked Neck broilers had more intensive growth thanks to favourable expression of gene for naked neck $(\mathrm{Na})$, which provides better adaptability to conditions of high ambient temperature. A hundred percent vitality of these birds can be correlated with the results of Rajkumar et al. (2010) which have established the superiority of naked neck genotypes of chickens ( NaNa and Nana) in immune status, all production traits and carcass quality in tropical climatic conditions. The results of our experiment indicated a tendency of better adaptation Redbro Naked Neck broilers in free range growing conditions, and complete concordance with the results of other studies is lacking as a result of moderate climatic conditions.

Similarly, the effect of housing system on performance of Redbro broiler was manifested largely through environmental conditions, primarily temperature. The positive impact of rearing in the poultry house was found on body weight $(\mathrm{p}<0.05)$, feed efficiency of broiler and mortality, which resulted in higher production index compared to free range reared Redbro broilers. Research results confirmed earlier studies (Škrbić et al., 2007) regarding the manifestation of the positive effect of growing conditions in the poultry house on body weight of Redbro broilers. Thanks to an intensive program of feeding during the experiment, significantly higher final body weights of Redbro broilers were achieved in both rearing systems in relation to the results of previous research. 
Table 3. Conformation, yield of dressed carcass and share of abdominal fat in broilers Redbro and Redbro Naked Neck reared at the free range

\begin{tabular}{|l|c|c|c|}
\hline \multirow{2}{*}{ Parameter } & \multicolumn{3}{|c|}{ Genotype } \\
\cline { 2 - 4 } & Redbro & $\begin{array}{c}\text { Redbro Naked } \\
\text { Neck }\end{array}$ & Significance \\
\hline Index of carcass confirmation measures (mean \pm SD) \\
\hline BW/SL, g/mm & $34.55 \pm 3.57$ & $32.24 \pm 2.59$ & $\mathrm{~ns}$ \\
\hline BW/KL, g/mm & $25.72 \pm 3.88$ & $24.20 \pm 2.88$ & $\mathrm{~ns}$ \\
\hline BW/BD, g/mm & $28.34 \pm 3.98$ & $27.04 \pm 2.96$ & $\mathrm{~ns}$ \\
\hline BW/TG, g/mm & $20.08 \pm 2.55$ & $18.82 \pm 1.96$ & $\mathrm{~ns}$ \\
\hline BA, degree & $122.83 \pm 7.40$ & $121.42 \pm 6.50$ & $\mathrm{~ns}$ \\
\hline \multicolumn{3}{|l}{} & $\mathrm{ns}$ \\
\hline Yield of dressed carcass (mean \pm SD) & $3055.8 \pm 462.92$ & $\mathrm{~ns}$ \\
\hline Body weight, g & $3207.5 \pm 601.65$ & $87.95 \pm 1.71$ & $\mathrm{~ns}$ \\
\hline Conventional dressing,\% & $88.30 \pm 1.23$ & $82.3 \pm 1.72$ & $\mathrm{~ns}$ \\
\hline Ready to roast,\% & $82.82 \pm 1.42$ & $74.44 \pm 1.65$ & \\
\hline Ready to grill,\% & $73.93 \pm 1.38$ & $2.57 \pm 0.92$ & \\
\hline Abdominal fat, \% & $2.55 \pm 0.73$ & & \\
\hline \multicolumn{2}{|l|}{$\%$}
\end{tabular}

BW-body weight; SL-shank length; KL-keel length; BD-breast depth; TG-thigh girth; BA-breast angle

Based on index values of carcass conformation measures shown in Table 3, higher values in Redbro broilers can be stated, which are the result of higher body weight, but also the lack of statistical confirmation of the established differences between genotypes. Similar situation was regarding the data for pre slaughter body weight, carcass yields - conventional dressed carcass, carcass ready to roast and ready to grill and the share of abdominal fat. Uniform relative carcass yields of two genotypes of moderate growth were recorded in the survey by Blagojevic et al. (2009), whereas significant differences were determined only relative to slow growing genotype.

Significant influence of the rearing system was exhibited in all index values of carcass conformation measures (Table 4) through a positive effect on body weight of Redbro chickens reared in the poultry house. However, in regard to carcass yield of conventionally dressed carcass, significantly higher value $(p<0.05)$ was found in the free range system of rearing Redbro broilers. Other indicators of carcass yield were very similar for both systems of rearing, and consistent with the research results Mikulski et al. (2011), Wang et al. (2009) who have showed that free range rearing system has not adversely affected the carcass yield of broiler chickens. Share of abdominal fat as expected was higher $(p>0.05)$ in the carcass of chickens reared in the poultry house, as a result of less physical activity. 
Table 4. Conformation, yield of dressed carcass and share of abdominal fat in broilers Redbro reared in the poultry house and at the free range

\begin{tabular}{|c|c|c|c|}
\hline \multirow{2}{*}{ Parameter } & \multicolumn{3}{|c|}{ Rearing system } \\
\hline & Poultry house & Free range & Significance \\
\hline \multicolumn{4}{|c|}{ Index of carcass conformation measures (mean \pm SD) } \\
\hline $\mathrm{BW} / \mathrm{SL}, \mathrm{g} / \mathrm{mm}$ & $39.35 \pm 3.77$ & $34.55 \pm 3.57$ & $* *$ \\
\hline $\mathrm{BW} / \mathrm{KL}, \mathrm{g} / \mathrm{mm}$ & $29.05 \pm 2.67$ & $25.72 \pm 3.88$ & * \\
\hline $\mathrm{BW} / \mathrm{BD}, \mathrm{g} / \mathrm{mm}$ & $32.49 \pm 2.67$ & $28.34 \pm 3.98$ & $* *$ \\
\hline $\mathrm{BW} / \mathrm{TG}, \mathrm{g} / \mathrm{mm}$ & $22.05 \pm 2.16$ & $20.08 \pm 2.55$ & $*$ \\
\hline BA, degree & $128.25 \pm 2.56$ & $122.83 \pm 7.40$ & $*$ \\
\hline \multicolumn{4}{|c|}{ Yield of dressed carcass (mean \pm SD) } \\
\hline Body weight, $g$ & $3681.7 \pm 490.99$ & $3207.5 \pm 601.65$ & * \\
\hline Conventional dressing, $\%$ & $87.30 \pm 1.13$ & $88.30 \pm 1.23$ & $*$ \\
\hline Ready to roast, $\%$ & $82.37 \pm 1.04$ & $82.82 \pm 1.42$ & ns \\
\hline Ready to grill, \% & $73.38 \pm 1.20$ & $73.93 \pm 1.38$ & ns \\
\hline Abdominal fat, $\%$ & $3.03 \pm 0.95$ & $2.55 \pm 0.73$ & ns \\
\hline
\end{tabular}

BW-body weight; SL-shank length; KL-keel length; BD-breast depth; TG-thigh girth;

BA-breast angle

Shares of major carcass parts in pre-slaughter body weight are shown in Table 5. Based on data for genotypes Redbro and Redbro Naked Neck can be stated the difference $(p<0.05)$ in the share of wing can be concluded, as well as statistically unconfirmed but highly significant difference in the share of the breast. Effect of rearing system also exhibited a statistically significant difference in the share of wings. In comparison with the results of Škrbić et al. (2007), a significantly higher share of the breast was identified, indicating a possible genetically predisposed conformational changes in Redbro broilers, which are important because the slower growing broiler genotypes are characterized mainly by the higher share of less valuable carcass parts compared to the fast-growing broilers (Mikulski et al. 2011). 
Table 5. The shares of individual major broiler carcass parts

\begin{tabular}{|c|c|c|c|}
\hline \multirow[b]{2}{*}{ Share, \% $\mathrm{TM}$} & \multicolumn{3}{|c|}{ Genotype } \\
\hline & Redbro & $\begin{array}{c}\text { Redbro Naked } \\
\text { Neck }\end{array}$ & Significance \\
\hline \multicolumn{4}{|l|}{ Free range } \\
\hline Breast & $19.72 \pm 1.95$ & $20.57 \pm 1.67$ & ns \\
\hline Drumsticks & $10.32 \pm 0.89$ & $10.31 \pm 0.67$ & ns \\
\hline Thighs & $12.80 \pm 0.64$ & $12.84 \pm 0.48$ & ns \\
\hline \multirow[t]{4}{*}{ Wings } & $8.98 \pm 0.52$ & $8.43 \pm 0.53$ & $*$ \\
\hline & & & \\
\hline & & Rearing system & \\
\hline & Poultry house & Free range & Significance \\
\hline \multicolumn{4}{|l|}{ Redbro } \\
\hline Breast & $19.44 \pm 1.51$ & $19.72 \pm 1.95$ & ns \\
\hline Drumsticks & $9.78 \pm 0.99$ & $10.32 \pm 0.89$ & ns \\
\hline Thighs & $12.94 \pm 0.73$ & $12.80 \pm 0.64$ & ns \\
\hline Wings & $8.28 \pm 0.49$ & $8.98 \pm 0.52$ & $* *$ \\
\hline
\end{tabular}

\section{Conclusion}

Based on the presented results, it can be concluded that the studied types of Redbro broilers (with plumage and naked neck) had different intensity of growth in certain phases of the experiment, which finally resulted in non-significant differences in body weight. There is a tendency of better adjustment of Naked Neck-type broiler chickens to free range growing conditions, which would probably be more pronounced in the extreme summer environment conditions. In regard to carcass quality, there were no significant differences except in the share of wings and non-significant but important difference in the share of the breast.

Controlled conditions of rearing in the poultry house positively affected the production performance through body weight and carcass conformation of Redbro broilers.

\section{Acknowledgment}

This research is part of the Project EVB: TR-31033 financially supported by Ministry of Education, Science and Technological Development of the Republic of Serbia. 


\title{
Proizvodne performanse i kvalitet trupa brojlera diferenciranog genetskog potencijala za porast
}

\author{
Z. Škrbić, Z. Pavlovski, M. Lukić, V. Petričević, D. Milić
}

\section{Rezime}

Istraživanje je sprovedeno sa ciljem uporedne analize proizvodnih performansi i kvaliteta trupa dve provenijence brojlera diferenciranog genetskog potencijala za porast (Redbro i Redbro Naked Neck) u uslovima intenzivne ishrane, kao i utvrđivanja efekta sistema gajenja (na ispustu i u objektu) na tovne performanse Redbro brojlera. Proizvodne performanse su prikazane u dva kontrolna perioda (42 i 84 dana). Kvalitet trupa analiziran je na osnovu konformacije, prinosa, udela vrednijih delova i sadržaja abdominalne masti. Redbro i Redbro Naked Neck brojleri su imali različit intenzitet porasta po fazama ogleda ali se u starosti 84 dana njihove telesne mase nisu značajno razlikovale (3382.44g prema $3236.0 \mathrm{~g})$. Manja efikasnost korišćenja hrane $(3.08 \mathrm{~kg}$ prema $2.79 \mathrm{~kg}$ ) i bolja vitalnost (100\% prema 97.33\%) utvrđena je kod Redbro Naked Neck brojlera. U pogledu kvaliteta trupa, nisu utvrđene značajne razlike osim u udelu krila. Pozitivan uticaj gajenja Redbro brojlera u objektu utvrđen je na telesnu masu $(\mathrm{p}<0.05)$, efikasnost korišćenja hrane i mortalitet brojlera, što je rezultiralo i većim proizvodnim indeksom (169.83 prema 140,37) u odnosu na Redbro piliće gajene na ispustu. Razlike u kvalitetu trupa su utvrđene na osnovu bolje konformacije, manjeg udela krila ali i manjeg prinosa klasično obrađenog trupa Redbro brojlera gajenih u objektu.

\section{References}

BLAGOJEVIĆ M., PAVLOVSKI Z., ŠKRBIĆ Z., LUKIĆ M., MILOŠEVIĆ N., PERIĆ L. (2009): The effect of genotype of broiler chickens on carcass quality in extensive housing system. Acta Veterinaria, 59, 1, 91-97.

BOGOSAVLJEVIĆ-BOŠKOVIĆ S., MITROVIĆ S., RADOVIĆ V., DOSKOVIĆ V. (2007): The age and housing system effects on the growth of broilers.

Biotechnology in Animal Husbandry 23, 5-6, 519- 525.

GRASHORN M.A., SERINI C. (2006): Quality of chicken meat from conventional and organic production. XII European Conference, Verona, Italy. World's Poultry Science Journal. Book of abstracts, 62, 268. CD-room

MIKULSKI D., CELEJ J., JANKOWSKI J., MAJEWSKA T., MIKULSKA M. (2011): Growth Performance, Carcass Traits and Meat Quality of Slower-growing 
and Fast-growing Chickens Raised with and without Outdoor Access. Asian-Aust. J. Anim. Sci., 24, 10: 1407-1416.

OWENS C., FANATICO A., PILLAI P., MEULLENET J., EMMERT J. (2006): Evaluation of alternative genotypes and production systems for natural and organic poultry markets in the US. XII European Conference, Verona, Italy. World's Poultry Science Journal. Book of abstracts, 62, 246. CD-room

PAVLOVSKI Z., LUKIĆ M., CMILJANIĆ R., ŠKRBIĆ Z. (2006): Konformacija trupova pilića. Biotehnologija u stočarstvu, 3-4, 83-97.

PAVLOVSKI Z., ŠKRBIĆ Z., LUKIĆ M. (2012): Autochthonous breed of chicken in Serbia: research or development. Proceedings of XV Feed Technology Symposium "Feed-to-Food", Novi Sad, Republic of Serbia, October 3-5, 127-133.

PAVLOVSKI Z., ŠKRBIĆ Z., LUKIĆ M., VITOROVIĆ D., PETRIČEVIĆ V. (2009a): Naked Neck - Autochthonous Breed of Chicken in Serbia: Carcass Characteristics. Biotechnology in Animal Husbandry, 25, 1-2, 1-10.

PAVLOVSKI Z., ŠKRBIĆ Z., LUKIĆ M., VITOROVIĆ D., PETRIČEVIĆ V., MILOŠEVIĆ N. (2009b): Naked Neck Chicken of Serbian and Foreign Origin: Carass Characteristic. $9^{\text {th }}$ International Symposium "Modern Trends in Livestock Production", October 2009, Belgrade. Biotechnology in Animal Husbandry, 25, 56, Book 2, 1023-1033.

RAJKUMAR U., REDDY B.L.N., RAJARAVINDRA K.S., NIRANJAN M., BHATTACHARYA T.K., CHATTERJEE R.N., PANDA A.K., REDDY M.R., SHARMA R.P. (2010): Effect of Naked Neck Gene on Immune Competence, Serum Biochemical and Carcass Traits in Chickens under a Tropical Climate. Asian-Aust. J. Anim. Sci., 23, 7: 867 - 872.

RISTIĆ M., DAMME K. (2002): Carcass value and meat quality of slow growing broiler lines upon feeding with rations according to organic conditions. Mitteilungsblatt BAFF 41, 146, 89-94.

RODIĆ, V., PERIĆ, L., MILOŠEVIĆ, N., SUPIĆ, N. (2003). Konkurentnost pilećeg mesa iz ekstenzivnog sistema držanja. Agroekonomika 32, Poljoprivredni fakultet, Novi Sad, 119-125.

ŠKRBIĆ Z., PAVLOVSKI Z., LUKIĆ M. (2007): Slaughter traits of slow growing broiler genotypes in different housing systems. Proceedings XVIII European Symposium on the Quality of Poultry Meat and XII European Symposium on the Quality of Eggs and Egg Products, Prague, 323-325.

ŠKRBIĆ Z., PAVLOVSKI Z., LUKIĆ M., TOMAŠEVIĆ D. (2010): Tehnologija proizvodnje pilećeg mesa u sistemu gajenja sa ispustom. Biotechnology in animal husbandry, 26, spec issue, $67-81$.

WANG K.H., SHI S.R., DOU T.C., SUN H.J. (2009): Effect of a free-range raising system on growth performance, carcass yield and meat quality of slow-growing chicken. Poultry Science 88: 2219-2223. 
YALCIN S, SETTAR P., OZKAN S., CAHANER A. (1997): Comparative Evaluation of Three Commercial Broiler Stocks in Hot Versus Temperate Climates. Poultry Science 76:921-929.

Received 30 November 2013; accepted for publication 15 December 2013 